\title{
Iwona Sowińska-Fruhtrunk
}

\section{Różnica i powtórzenie jako aspekty reprezentacji w Variationen für Orchester op. 31 Arnolda Schönberga'}

\section{Abstract}

\section{Difference and Repetition As the Aspects of Representation} in Arnold Schoenberg's Variations for Orchestra Op. 31

The article focuses on the issues of difference and repetition, as defined by Gilles Deleuze, and their possible application to Arnold Schoenberg's dodecaphonic work, Variations for Orchestra Op. 31. Although Schoenberg's reflection on these problems comes from the earlier years than Deleuze's, the correspondence of understanding the difference and repetition between them is striking. Two other terms by Deleuze and Guattari applied to the work are becoming and refrain. Repetition and refrain are associated with the representational moment in the work (motif B-A-C-H as a quote and as a type of refrain) while difference and becoming are associated with the anti-representational moment (dodecaphonic technique, developing variation technique, etc.).

1 Publikacja powstała $\mathrm{w}$ wyniku realizacji projektu badawczego o numerze 2016/21/N/HS2/o2676, finansowanego ze środków Narodowego Centrum Nauki. 


\section{Keywords}

Arnold Schoenberg, Gilles Deleuze, Variations for Orchestra Op. 31, dodecaphony, difference and repetition

Dwa impulsy walczą ze sobą w człowieku: potrzeba powtórzenia przyjemnych bodźców i przeciwne mu pragnienie różnorodności, zmiany, nowych stimuli. [...] Te dwa impulsy często łączą się w jeden relatywnie powszechny impuls, charakterystyczny dla drapieżnych zwierząt: wzięcia w posiadanie. [...] Stojąc twarzą w twarz z dylematem, czy uprzywilejowane jest powtórzenie bodźców, czy też innowacja, umysł ludzki zdecydował także „wziąć w posiadanie”; stworzył system².

(Arnold Schönberg)

Lata 1914-1923 były dla Schönberga z jednej strony okresem kształtowania się i dojrzewania „metody komponowania za pomocą dwunastu dźwięków"3, z drugiej zaś czasem ograniczenia wypowiedzi artystycznej. Wybuch I wojny światowej nie sprzyjał komponowaniu (twórca był dwukrotnie powoływany do armii austriackiej), z kolei na lata 1917-1920 przypada wzrost zainteresowania prowadzonym przez Schönberga „seminarium kompozycji”, któremu musiał w związku z tym poświęcić sporo czasu. Wówczas pojawia się także idea oratorium Die Jakobsleiter, wiążąca się z koniecznością napisania tekstu inspirowanego religijno-mistycznymi i etycznymi rozważaniami kompozytora ${ }^{4}$. Pierwszym utworem, w którym krystalizuje się metoda dodekafoniczna, jest Fünf Klavierstücke op. 23 z 1923 roku. W październiku 1925 roku Schönberg został mianowany profesorem kompozycji w Pruskiej Akademii Sztuk Pięknych w Berlinie (w miejsce zmarłego

2 A. Schoenberg, Theory of Harmony, tłum. na ang. R.E. Carter, Berkeley-Los Angeles 1983, s. 48. Angielska wersja cytowanego fragmentu brzmi: „Two impulses struggle with each other within man: the demand for repetition of pleasant stimuli, and the opposing desire for variety, for change, for a new stimulus. These two impulses often unite in one relatively common impulse characteristic of beasts of prey: the impulse to take possession. [...] Faced with the dilemma, whether repetition of stimuli or innovation be preferable, the human intellect decided here, too, to take possession; it founded a system"; tłum. I. S.-F. Wszystkie tłumaczenia i wyróżnienia, jeśli nie wskazano inaczej, pochodzą od autorki artykułu.

3 Por. L. Rognoni, Wiedeńska szkoła muzyczna. Ekspresjonizm i dodekafonia, tłum. H. Krzeczkowski, Kraków 1978, s. 88.

4 Tamże. 
Ferruccia Busoniego); zasiadał również w senacie uczelni. Ze względu na stan zdrowia kompozytor rozpoczął tę pracę dopiero z początkiem 1926 roku, przygotowując się jednocześnie do zastosowania metody dodekafonicznej na gruncie dużej formy orkiestrowej. Początkowo miała to być Passacaglia, która ostatecznie pozostała nieukończona; w międzyczasie powstała także Suita op. 29 oraz szereg szkiców do wariacji, datowanych na maj 1926 roku$^{5}$.

Według Therese Muxeneder Variationen für Orchester op. 31 powstawały etapami: pierwszy etap (do piątej wariacji włącznie) przebiegał bez zakłóceń, później nastąpiła przerwa aż do 1928 roku (poświęcona na opracowywanie tekstu Der biblische Weg, zapowiadającego tematykę opery Moses und Aron), wreszcie ostatecznego impulsu do ukończenia dzieła dostarczyło zamówienie złożone przez Wilhelma Furtwänglera ${ }^{6}$. Variationen zostały ukończone 21 sierpnia 1928 roku podczas wakacji w Roquebrune-Cap-Martin we Francji. Mimo trudności technicznych, w jakie obfitowało dzieło, Furtwängler zaplanował tylko trzy próby, co spowodowało, że prawykonanie utworu 2 grudnia 1928 roku w Berlinie było całkowitą porażką. Variationen zdobyły uznanie publiczności dopiero podczas wykonania we Frankfurcie w lutym 1931 roku, które zostało poprzedzone autorskim wprowadzeniem. W wyemitowanym niedługo później wykładzie radiowym Schönberga na temat utworu (w marcu 1931 roku) przywołanych zostało aż siedemdziesiąt przykładów muzycznych, pojawiły się także liczne nawiązania do kryterium zrozumiałości koherencji, logiki muzycznej oraz wyjaśnienia odniesień do tradycji ${ }^{7}$. Muxeneder zwraca w tym kontekście uwagę na następującą autorefleksję kompozytora:

Variationen für Orchester zbliżają się bez wątpienia do symfonicznego sposobu projektowania [...], wariacje są rodzajem albumu zawierającego ujęcia miejsca lub krajobrazu, ukazującym cechy indywidualne. Natomiast symfonia jest rodzajem pa n o r a m y, umożliwiającej oddzielne spojrzenie na każdy obraz, choć w rzeczywistości obrazy te są silnie wzajemnie powiązane i stopione ze sobą ${ }^{8}$.

5 T. Muxeneder, Variationen für Orchester [Variations for Orchestra] Op. 31 (1926-28), http://www.schoenberg.at/index.php/en/joomla-license-sp-1943310036/variationen-fuer-orchester-op-31-1926-1928 [dostęp: 02.08.2017].

6 Tamże.

7 Tamże.

8 Tamże. 


\section{Deleuzjańskie pojęcia powtórzenia, różnicy i refrenu}

Istotnym elementem refleksji filozoficznej w XIX wieku, m.in. w myśli Sørena Kierkegaarda, stała się idea powtórzenia. To z kolei poskutkowało wydobyciem na pierwszy plan przez myślicieli drugiej połowy XX wieku pojęcia różnicy i tym samym - dojściem do kresu reprezentacji, a wręcz do antyreprezentacji. Zapoczątkowany przez modernistów odwrót od reprezentacji staje się także jednym ze znaków rozpoznawczych szeroko rozumianego postmodernizmu, a zwłaszcza poststrukturalizmu, m.in. wizjonerskiej filozofii Gilles'a Deleuze'a (1925-1995). Kluczowym problemem dla myśli Deleuze’a jest odwrócenie relacji metafizycznej między tożsamością i różnicą. Filozof uważa, że za sprawą dominacji (i oczywistości) tożsamości, która jako pierwsza przykuwa naszą uwagę, traktujemy różnicę jedynie jako opozycję tożsamości, a nie „rzecz samą w sobie”. Z kolei powtórzenie w ujęciu Deleuzéa posiada paradoksalny charakter. Tomasz Załuski wyjaśnia, że sytuacja idealnego powtórzenia jest niemożliwa, a to ze względu na różny „kontekst wewnętrzny” powtórzenia i oryginału9. Ponieważ już sam fakt powtórzenia implikuje obecność pewnych modyfikacji, uświadomiona zostaje rola różnicy. Wydawałoby się, że takie rozumienie różnicy czyni reprezentację konceptualnie niemożliwą. Konkluzja ta dotyczy jednak wyłącznie reprezentacji rozumianej jako imitacja, a nie jako mimesis. Ta druga bowiem zakłada akt kreacji i nie wymaga ani absolutnego, ani nawet częściowego podobieństwa do oryginału.

Reinterpretacja powtórzenia Deleuze’a ma daleko idące konsekwencje. Jak zauważa Załuski:

Deleuze nie postuluje porzucenia jednego, określonego paradygmatu powtórzenia na rzecz innego, lecz bardziej radykalne przejście od paradygmatycznego ujęcia powtórzenia do ujęcia, które należałoby określić mianem „a-paradygmatycznego"10.

Innym pojęciem zreinterpretowanym przez Deleuze'a - wraz z radykalnym psychoanalitykiem Félixem Guattarim - jest refren

9 T. Załuski, Modernizm artystyczny i powtórzenie. Próba reinterpretacji, Kraków 2012, s. 5.

10 Tamże, s. 25. 
(ritournelle $)^{11}$. Jest on rozumiany przez filozofa w szeroki sposób, pozostając przede wszystkim w ścisłym związku z pojęciami terytorializacji, deterytorializacji i reterytorializacji ${ }^{12}$, aczkolwiek samo sedno pozostaje zbieżne z muzycznym sposobem rozumienia refrenu. Deleuze i Guattari tak piszą o ritournelle -

\section{[...] jest on terytorialny, jest terytorialnym układem. Ptasi śpiew. Swym świergotem ptaki wyznaczają terytorium. Greckie skale, indyjskie rytmy same w sobie są terytoriami, prowincjami, regionami. Refren przybierać może inne jeszcze funkcje: miłosną, zawodową czy społeczną, liturgiczną bądź kosmiczną. Zawsze jednak ciągnie za sobą pewną ziemię [... $]^{13}$.}

Z punktu widzenia muzyki istotna jest jeszcze jedna charakterystyka: „Refren to rytm i melodia, które uległy terytorializacji, zyskały bowiem wyrażeniowość. A zyskują wyrażeniowość dlatego, że dokonują terytorializacji. Nie kręcimy się tutaj w kółko. Chcemy przez to jedynie powiedzieć, że zachodzi pewien samoczynny ruch jakości wyrażeniowych" ${ }^{14}$. Deleuze i Guattari wyróżniają terytorialne motywy (oblicza lub postaci rytmiczne) i terytorialne kontrapunkty (krajobrazy melodyczne $)^{15}$. Autorzy proponują także klasyfikację refrenów:

1) refreny terytorialne, wyszukujące, oznakowujące i układające pewne terytorium; 2) refreny funkcji sterytorializowanych, przybierające szczególną funkcję w ramach układu (kołysanka terytorializująca zasypianie dziecka, pieśń miłosna terytorializująca seksualność i oblubieńca/oblubienicę, przyśpiewka robocza, terytorializująca wykonywany zawód i pracę, przyśpiewka kupiecka, terytorializująca podział i dobra); 3) refren jako coś, co oznakowuje teraz nowe układy, co przechodzi do nowych układów na drodze deterytorializacji - reterytorializacji [...]; 4) refreny zbierające czy gromadzące siły, bądź w obrębie terytorium, bądź w celu jego opuszczenia

11 G. Deleuze, F. Guattari, Tysiąc plateau, tłum. M. Herer, Warszawa 2015.

12 Pojęcie terytorializacji dotyczy terytorium jako obszaru (sensu largo), którego granice są wyznaczane nie przez jego funkcje, lecz ekspresję. Deterytorializacja to opuszczenie terytorium; reterytorializacja to powrót na terytorium po jego uprzednim opuszczeniu. Por. G. Deleuze, F. Guattari, dz. cyt., s. 379-387.

13 G. Deleuze, F. Guattari, dz. cyt., s. 379-38o.

14 Tamże, s. 386.

15 Tamże, s. 387. 
(to śpiewki starcia bądź śpiewki do odejścia, niekiedy torujące drogę absolutnej deterytorializacji) [... $]^{16}$.

Takie ujęcie refrenu nosi pewien rys rytualności, także za sprawą powiązania go z ideą cyrkularności, wiecznego powrotu ${ }^{17}$. To właśnie za sprawą refrenu, jako elementu stabilizującego i powtarzalnego, idea reprezentacji staje się znów możliwa do zastosowania.

\section{Muzyczne środki reprezentacji. Powtórzenie, refren i różnica}

Powtórzenie i różnica są pojęciami postrzeganymi tradycyjnie w relacji opozycji. Co więcej, jak sugerował Jacques Derrida, „zachodnia metafizyka to system funkcjonujący jako zatarcie różnicy"18, zdominowany przez powtórzenie. Różnica „budzi grozę”, gdyż to, co inne, „zostaje odrzucone w sferę obcości"19. Chodzi zatem nie o samą opozycję, lecz o sposób jej rozumienia - jako wprowadzającą element inności, wręcz wrogości. Dopiero dwudziestowieczna reinterpretacja tych pojęć przyniosła dostrzeżenie w różnicy samodzielnej, pełnoprawnej jakości, zwłaszcza za sprawą Deleuzjańskiego „pluralizmu” (zwanego empiryzmem), podającego $\mathrm{w}$ wątpliwość myślenie dialektyczne ${ }^{20}$. W analizie muzycznej wciąż jednak zwraca się większą uwagę na elementy unifikujące, syntetyzujące, niż na te różnicujące i sprawiające, że dzieło (lub jego fragmenty) wykazuje indywidualną i oryginalną relację z rzeczywistością muzyczną i pozamuzyczną. Michael Cherlin, wyliczając tego rodzaju „błędy” analityczne, wskazuje na takie problemy jak: 1) niewystarczające i niewłaściwie ukierunkowane podkreślanie roli opozycji i kontrastów w muzyce; 2) synteza unifikująca opozycje jako cel analizy; 3) poszukiwanie za wszelką cenę momentu kadencyjnego, co umniejsza wagę prowadzących do niego akordów ${ }^{21}$. Marginalizowane

16 Tamże, s. 398-399.

17 G. Deleuze, Różnica i powtórzenie, tłum. B. Banasiak, K. Matuszewski, Warszawa 1997, s. 34 .

18 Cyt. za: B. Banasiak, Bez różnicy, [w:] G. Deleuze, Różnica i powtórzenie, tłum. B. Banasiak, K. Matuszewski, Warszawa 1997, s. 5.

19 Tamże.

20 Tamże, s. 19.

21 M. Cherlin, Dialectical Opposition in Schoenberg's Music and Thought, „Music Theory Spectrum" 22 (2000), nr 2, s. 165. 
są w ten sposób metody, dzięki którym w myśli muzycznej kreowana lub intensyfikowana jest opozycja.

Akt powtórzenia stanowi fundament reprezentacji rozumianej jako ponowne przedstawienie, uobecnienie, powiązane $\mathrm{z}$ aktem kreacji. Z powtórzenia wynikać może również „nie-powtórzenie”, które znajduje wykładnię teoretyczną w omówionej wyżej filozofii różnicy, począwszy od Henri Bergsona aż do Gilles’a Deleuze’a. Z kolei różnica, według Deleuzéa, jest podstawą „stawania się” (devenir), co oznacza zerwanie jakichkolwiek więzów z reprezentacją opartą na powtórzeniu. Według niektórych badaczy (m.in. Dorothei Olkowski i Elisabeth Grosz ${ }^{22}$ ) to właśnie w refleksji tego filozofa doszło do „ruiny reprezentacji” jako takiej, inni natomiast (np. Eric Prieto ${ }^{23}$ ) uważają, że reprezentacja stanowi tak fundamentalny element wszelkiej ludzkiej aktywności, iż nie ma od niej ucieczki.

W muzyce za modelowy przykład upadku reprezentacji uchodzi nierzadko dodekafonia. Jednak zarzut „matematycznej abstrakcji”, stawiany często dodekafonicznym dziełom Schönberga, przy bliższym poznaniu autorefleksji twórcy i idei stojących za jego twórczością okazuje się bezzasadny. Problem ten celnie podsumował Julian Johnson:

\footnotetext{
Muzyka nigdy nie jest redukowalna do poziomu abstrakcji występującego w matematyce, częściowo dlatego, że istnieje w materialnej (słyszalnej) postaci, ale przede wszystkim dlatego, że materiał, którym się posługuje, jest historycznie ukształtowany i rezonuje rzeczami materialnymi. Abstrakcja w muzyce jest, być może, lepiej zrozumiała nie jako nieobecność treści materialnej, lecz jako szczególna jej transformacja24.
}

W Variationen für Orchester Schönberga formy serii, lustrzane zestawienia heksachordów lub cząstek-motywów serii, "gra” kilkoma zaledwie dźwiękami serii i komplikacje kontrapunktyczne mogłyby sugerować poziom reprezentacji o charakterze quasi-mimetycznym, refleksywnym, natomiast motyw B-A-C-H, interwał trytonu i kwinty czystej - poziom reprezentacji o charakterze metaforyczno-symbolicznym.

22 D. Olkowski, Gilles Deleuze and the Ruin of Representation, Berkeley 1999; E. Grosz, Chaos, Territory, Art: Deleuze and the Framing of the Earth, New York 2008.

23 E. Prieto, Deleuze, Music, and Modernist Mimesis, https://www.academia. edu/580419/Deleuze_Music_and_Modernist_Mimesis [dostęp: 12.03.2017]; tenże, Listening In: Music, Mind, and the Modernist Narrative, London 2002.

24 J. Johnson, Webern and the Transformation of Nature, Cambridge 1999, s. 215-216. 
Jednak ze względu na wyjątkową adekwatność wariacji jako formy w kontekście rozważań nad powtórzeniem i różnicą, a także ze względu na obecność kwestii powtórzeń i „wariantów” w refleksji teoretycznej Schönberga, na tych właśnie pojęciach skupiona zostanie uwaga w dalszej części artykułu.

Variationen für Orchester ujęte zostały w formę dziewięciu wariacji $z$ introdukcją, tematem i rozbudowanym finałem. Introdukcja i finał wiążą cały cykl poniekąd w formę łuku, dzięki obecności motywu-cytatu B-A-C-H oraz istotnych strukturalnie interwałów kwinty czystej i trytonu. Tworzą się w ten sposób trzy w pewnym sensie niezależne płaszczyzny brzmieniowo-semantyczne: seria dodekafoniczna, cytat oraz dialektyka interwałów trytonu (jako pierwszego interwału serii) i kwinty czystej. Co interesujące, o ile punktem wyjścia dla dziewięciu wariacji jest serialny temat (zob. przykład 1), o tyle finał stanowi rodzaj wariacji podwójnych, w których tematem uprzywilejowanym staje się B-A-C-H. Pojawia się w nim także nowy motyw, na którego rolę strukturalną wskazuje Marija Benič Zovko ${ }^{25}$. Większość wariacji (podobnie jak introdukcja i temat) wykazuje formę trzyczęściową ABA'. Obecność w introdukcji półtonu $b$ - $a$ zapowiada pojawienie się cytatu B-A-C-H; jest rodzajem antycypacji, a jednocześnie „odsłonięcia" motywu, którego zalążek ukryty jest w samym temacie. Interwał trytonu stopniowo ewoluuje w motyw początkowy tematu, czyli następuje stopniowe „rozwijanie” serii w sposób linearny (zarówno pojęciowo, jak i czasowo). Bachowski motyw-kryptogram pojawia się po raz pierwszy w pełnej formie w taktach 24-25, w partii pierwszego puzonu, dookreślonej jako pp dolce.

Temat wariacji zawiera całą serię, ukazaną w sposób melodyczny, linearny, z towarzyszeniem akompaniamentu, w partii wiolonczeli solo, a następnie także pierwszych skrzypiec, w postaci zasadniczej, inwersji raka, raku i inwersji. Jak zauważa Hartmut Krones, frazy tematu układają się w odcinki: pięciodźwiękowy, czterodźwiękowy, trzydźwiękowy itd. ${ }^{26}$, jednak wewnętrzne odczucie wskazuje na wspomnianą już formę trzyczęściową ABA'. Możliwa jest także inna interpretacja, podążająca za postaciami serii: cztery odcinki naprzemiennie pięcio- i siedmiotaktowe (przykład 1).

25 M. Benič Zovko, Twelve-Tone Technique and Its Forms: Variation Techniques of Arnold Schoenberg's "Variations for Orchestra” Op. 31, „International Review of the Aesthetics and Sociology of Music" 38 (2007), nr 1, s. 44.

H. Krones, Arnold Schönberg, Wien 2005, s. 98. 

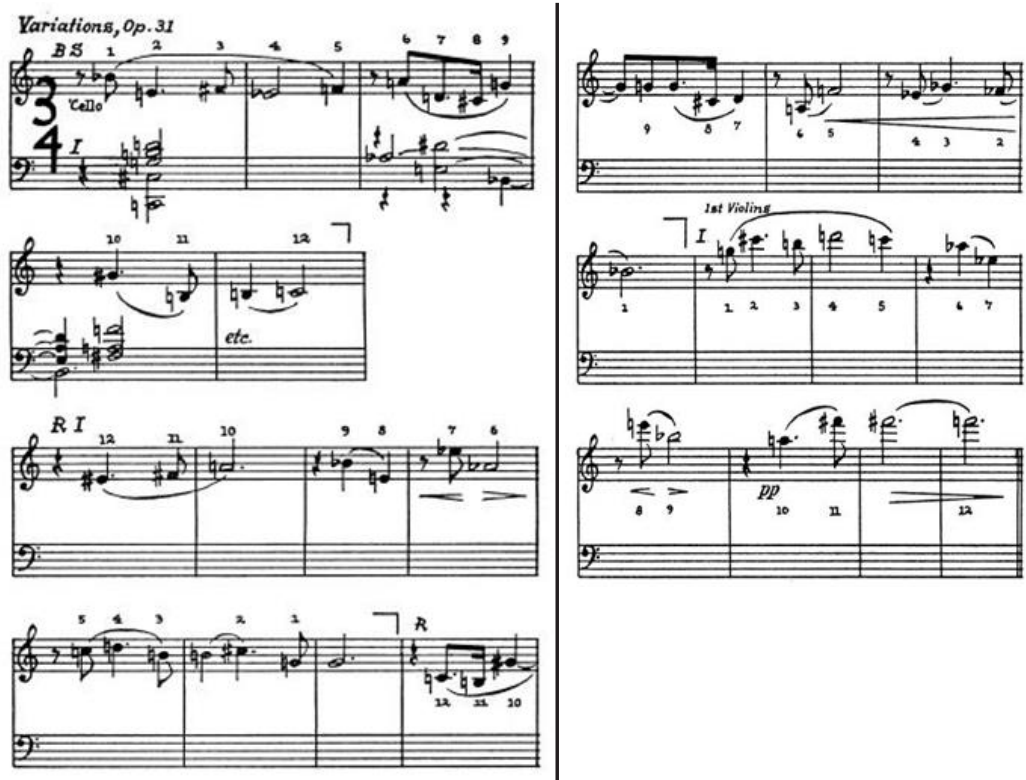

Przykład 1. A. Schönberg, Variationen für Orchester op. 31, t. 34-57, temat wariacji. Źródło: A. Schoenberg, Composition with Twelve Tones (1), [w:] tegoż, Style and Idea, Berkeley 2010, S. $236^{27}$.

Finał stanowi niemal 1/3 całego utworu i, jak już zasygnalizowano, jest rodzajem podwójnych wariacji: na temat właściwy oraz cytatu B-A-C-H, wzbogaconych o motyw lokalny, specyficzny dla finału ${ }^{28}$. Wykazuje budowę trzyczęściową: A (Mäßig schnell) B (Grazioso) C (Presto), w której części B i C zawierają kombinację wszystkich motywów-tematów. Pojawiające się pod koniec finału Adagio jest nieco nostalgicznym powrotem tematu. W finale temat właściwy wariacji nie jest motorem techniki wariacyjnej - wszystkie trzy motywy są traktowane jak tematy quasi-przetworzenia.

27 We wszystkich przykładach nutowych zastosowano partyturę in C.

28 M. Benič Zovko, dz. cyt., s. 44. 


\section{Powtórzenie i refren jako reprezentacja}

1) Materiał dźwiękowy

Temat wariacji formuje seria dodekafoniczna w postaci zasadniczej oraz jej przekształcenia (inwersja raka, rak, inwersja). Postać zasadnicza jest skonstruowana, jak zwykle u Schönberga, w sposób wskazujący od razu na uprzywilejowanie interwałów trytonu i sekundy małej (przykład 2).

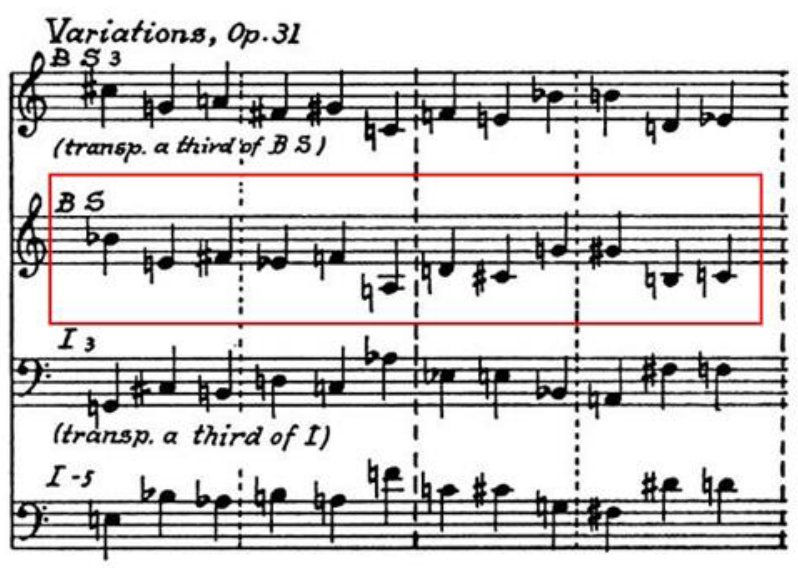

Przykład 2. Postać zasadnicza serii Variationen für Orchester (w ramce). Źródło: A. Schoenberg, Composition with Twelve Tones (1), [w:] tegoż, Style and Idea, Berkeley 2010, s. 236.

Jak zauważa Marija Benič Zovko, temat jako główna melodia pojawia się w wariacjach: I, II, III, VIII, IX, natomiast w wariacjach IV, V, VI i VII stanowi część akompaniamentu (zwłaszcza w V, VI i VII jest „wchłonięty” przez materiał dźwiękowy całego przebiegu muzycznego ${ }^{29}$. Zdaniem Carla Dahlhausa w tych wariacjach temat jest zaledwie „symbolizowany”, a sam materiał dźwiękowy zyskuje nowe znaczenie ${ }^{30}$.

29 Tamże, s. 44-45.

30 C. Dahlhaus, Meisterwerke der Musik. Schönberg: „Variationen für Orchester”, op. 31, München 1968, s. 17. 
W opozycji do poglądu Wolfganga Rihma, że kryptogram B-A-C-H nie jest bezpośrednio zawarty $\mathrm{w}$ samej serii, warto przedstawić, jaką ujawnia ona konstrukcję interwałową:

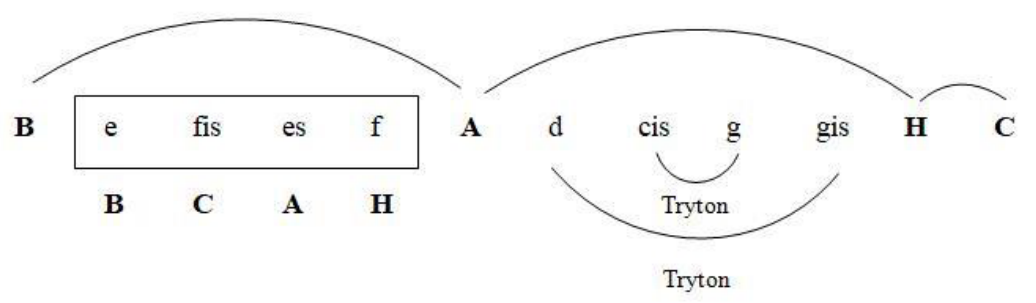

Schemat 1. Wewnętrzna konstrukcja interwałowa serii dodekafonicznej w Variationen für Orchester op. 31 Arnolda Schönberga. Opracowanie własne.

Uwagę zwraca także obecność kwint czystych: „pośrodku” serii, na przecięciu heksachordów ( $a-d, \mathrm{w}$ inwersji) oraz wynikających $\mathrm{z}$ drugich, w kolejności od początku i od końca, dźwięków serii $(e-h)$. Zawiera się w tej budowie pewien szczególny rodzaj symetrii, która - choć nieoczywista - wpływa na konstrukcję całego cyklu. Taka interpretacja jest uprawomocniona twierdzeniem samego kompozytora o jedności przestrzeni muzycznej ${ }^{31}$, która umożliwia uwzględnienie między dźwiękami serii z jednej strony relacji linearnych, z drugiej - właśnie przestrzennych. Podkreślony zostaje cyrkularny charakter nie tylko serii, ale całej trójwymiarowej konstrukcji ideowo-muzycznej: serii, motywu B-A-C-H oraz interwałów kwinty czystej i trytonu. Zatem już na poziomie samej postaci zasadniczej serii istnieją dwie wersje motywu-cytatu, dwa interwały trytonu i dwie kwinty czyste. Takie symultaniczne ujęcie zróżnicowanego (także pod względem symbolicznym) wyjściowego materiału dźwiękowego skłania do rozważań na temat powtórzenia i różnicy, a także tożsamości. Jednoczesna sukcesywność i symultaniczność przebiegu serii przyczynia się do specyficznej gry czasów: płynącego, zawieszonego i skondensowanego. Konstrukcja serii sprawia, że mogą z niej powstawać motywy o zróżnicowanym, a jednocześnie rozpoznawalnym charakterze. Jednak główną zaletą pozostaje, postulowana przez kompozytora, przestrzenna unifikacja

31 A. Schoenberg, Style and Idea, Berkeley 2010, s. 220. 
materiału dźwiękowego ${ }^{32}$. Zatem seria Schönbergowska nie jest tożsama z ,uszeregowaniem”, jak pisał o serii dodekafonicznej Krzysztof Szwajgier ${ }^{33}$.

Introdukcja Variationen ma charakter ostinatowy, dla którego typowe jest doświadczenie zatrzymania, zawieszenia czasu (technika znana już z Erwartung op. 17). Warto wspomnieć, że wzór dla dzieła stanowił szkic utworu Passacaglia für Orchester, nad którym Schönberg zaczął pracować w 1920 roku. Ethan Haimo sugeruje, że to właśnie wzorzec passacaglii jest charakterystyczny dla pierwszych ośmiu wariacji ${ }^{34}$. Temat pojawia się np. w wariacji I jako rodzaj cantus firmus (w klarnecie basowym, fagotach i kontrafagocie), w wariacji II w podobny sposób, lecz w zmodyfikowanej inwersji (w skrzypcach solo). Występuje zatem na jednej płaszczyźnie w niezmienionej postaci, natomiast drugą płaszczyznę stanowi zróżnicowany materiał motywiczny wywiedziony z serii. Jak zauważa Haimo, taka wielowymiarowa (sześcioskładnikowa) wersja serii obecna jest także w wariacji V: seria pojawia się tam horyzontalnie (w partii klarnetu basowego i fagotów), ale jej składniki są jednocześnie zestrojone wertykalnie ${ }^{35}$. Podstawowymi interwałami są sekunda mała oraz septyma wielka i nona mała. Kantylenowy temat pierwszych i drugich skrzypiec oparty jest na ostinatowej komórce zbudowanej z sekund małych, przypominającej, według Carla Dahlhausa ${ }^{36}$, bardziej motyw B-A-C-H niż temat właściwy wariacji (przykład 3).

\section{2) Faktura polifoniczna}

Faktura utworu jest polifoniczna, zwłaszcza w wymiarze przestrzennym (rozumianym jako specyficzny rodzaj Schönbergowskiej Klangfarbenmelodie). Technika polifoniczna dotyczy nie tylko elementów wywiedzionych z materiału dodekafonicznego, ale także motywu B-A-C-H i motywu trytonu, który zyskuje dzięki temu pewną samodzielność i niezależność. W przypadku polifonii Schönbergowskiej powstaje pytanie, na ile ten rodzaj techniki jest unifikujący, a na ile różnicujący.

\footnotetext{
32 Tamże, s. 244.

33 K. Szwajgier, Webern, B-A-C-H, C-A-G-E i Czwórca, [w:] Muzyka w kontekście kultury, red. M. Janicka-Słysz, T. Malecka, K. Szwajgier, 2001, s. 745.

34 E. Haimo, Variationen für Orchester, op. 31, [w:] Schönberg, Interpretationen seiner Werke, red. G. Gruber, Wien 2002, s. 467.

35 Tamże, s. 476.

36 C. Dahlhaus, Arnold Schönberg, Variationen für Orchester, München 1968, s. 17.
} 
Dzięki polifonii różne płaszczyzny utworu mogą współistnieć w sposób niepodważający ich tożsamości (także symbolicznej). Jednym z nielicznych przykładów odstępstwa od zasady polifonii jest motoryczna, ostinatowa wariacja VIII (przykład 4).

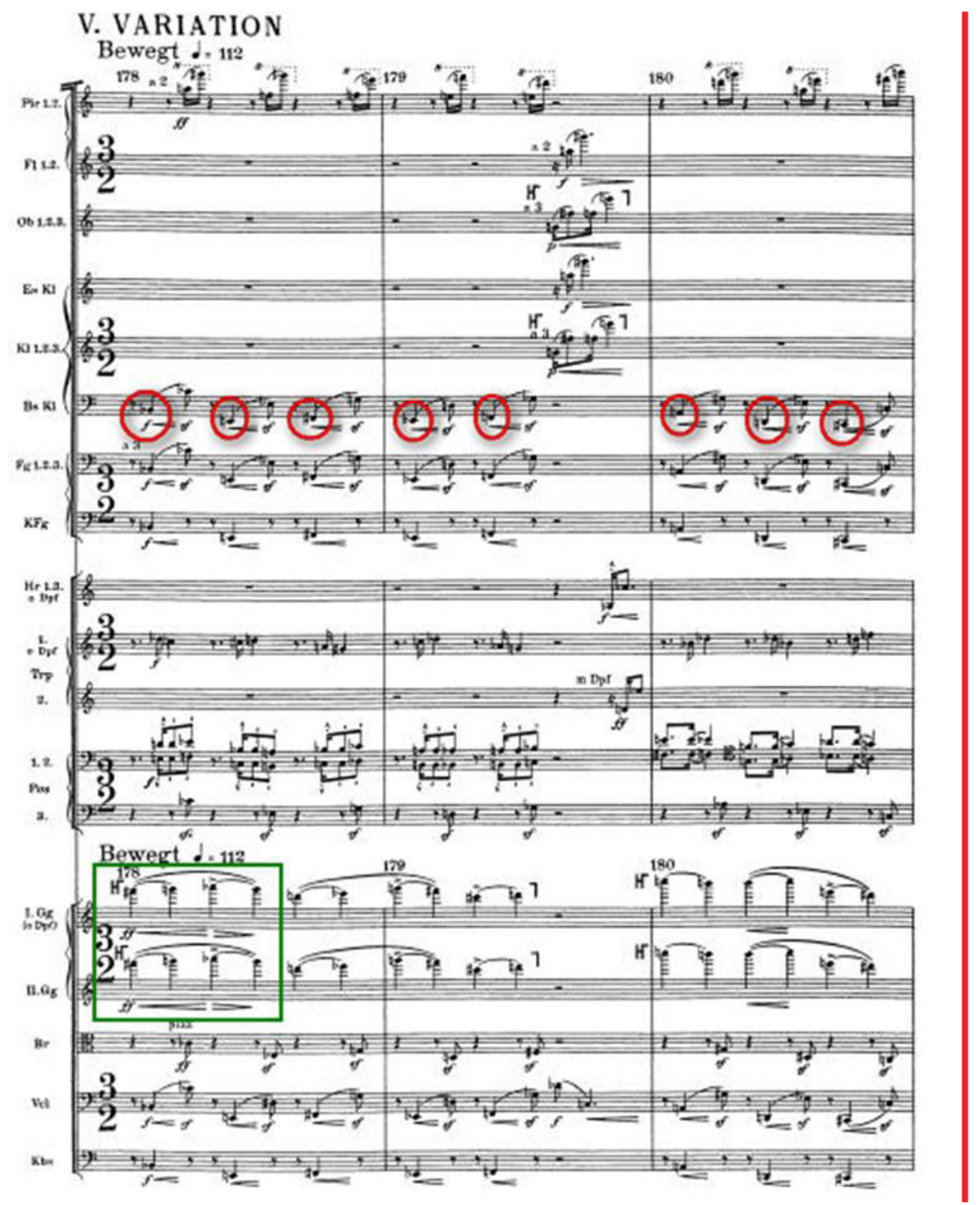

Przykład 3. A. Schönberg, Variationen für Orchester op. 31, wariacja V, t. 178-180. W prostokącie zaznaczono komórkę dźwiękową przypominającą motyw B-A-C-H, natomiast w okręgach - kolejne dźwięki tematu wariacji. Wszystkie przykłady zamieszczone za zgodą wydawnictwa Universal Edition Wien. 

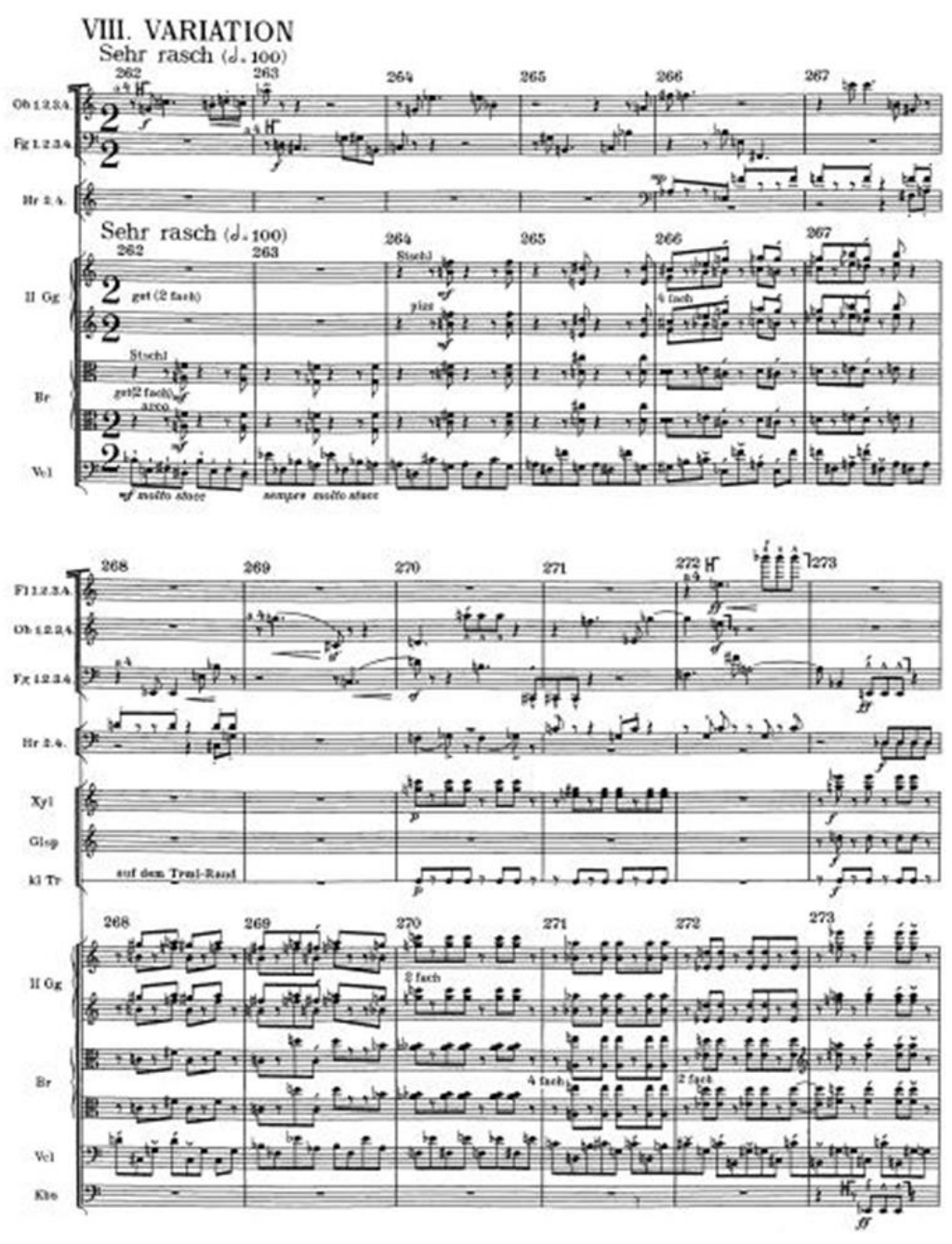

Przykład 4. A. Schönberg, Variationen für Orchester op. 31, wariacja VIII, t. 262-273. Przykład ostinato.

3) „Muzyka w muzyce”

Zjawisko „muzyki w muzyce” zostało dość szeroko omówione przez polskich muzykologów, m.in. podczas spotkań w Baranowie Sandomierskim ${ }^{37}$. Mieczysław Tomaszewski, jako jeden $\mathrm{z}$ badaczy

37 Autorka nie bierze pod uwagę definicji „muzyki w muzyce” proponowanych przez narratologie; por. K. Berger, Diegesis and Mimesis: The Poetic Modes and the Matter of Artistic Presentation, „The Journal of Musicology” 12 (1994), nr 4, s. 408. 
wypowiadających się na temat tego zagadnienia, zwrócił uwagę na pierwszoplanowy charakter relacji, wyrażający się - w sensie metaforycznym - w myśleniu bardziej interwałem niż dźwiękiem ${ }^{38}$, z zaakcentowaniem roli różnicy między dziełami. Autor zwraca także uwagę na wkroczenie w pola napięć „między tym, co dane i przejęte a tym, co dodane, wymyślone samodzielnie"39. Tomaszewski widzi $\mathrm{w}$ tych napięciach przede wszystkim rys dialektyczny, opozycyjny, wyrażający się m.in. w parach: cudze - własne; pierwotne - wtórne; ustalone, zapisane - zmienne, oddane improwizacji; dawne - współczesne; dalekie - bliskie; przynależne gatunkowi, rodzajowi, stylowi i formie - przynależne indywidualnemu dziełu ${ }^{40}$. Z kolei Bohdan Pociej zwraca uwagę, że aby zaistniała „muzyka w muzyce”, niezbędna jest pełna świadomość kompozytora, czyli: „a) świadomość dwóch czasów - «teraz» i «niegdyś», b) świadomość brania «cudzego» materiału, c) świadomość własnej postawy" ${ }^{41}$. Zdaniem Reginy Chłopickiej motyw B-A-C-H (rozpatrywany w kontekście Pasji według św. Łukasza Krzysztofa Pendereckiego) łączy się z kręgiem najwyższych wartości, odwiecznym i niezmiennym, tajemniczym i nieogarnionym $^{42}$. Muzyka zawiera zatem nie tylko muzykę, ale także przywołuje całą sferę symboliczną. Motyw B-A-C-H pełni w dziele funkcję cytatu dosłownego, który Tomaszewski definiuje jako „przytoczenie w utworze własnym muzyki cudzej dokonane po pierwsze - w pełni świadomie, po drugie zaś w pełni jawnie, czyli uczynione w sposób wyróżniony, ułatwiający słuchaczowi identyfikację oraz zrozumienie celu i sensu owego przytoczenia" ${ }^{43}$. Krzysztof Szwajgier uważa, że struktura B-A-C-H nie jest właściwie ani tematem, ani motywem, lecz raczej metaforą:

38 M. Tomaszewski, Na otwarcie: dlaczego muzyka w muzyce, [w:] Spotkania muzyczne w Baranowie 1977. Muzyka w muzyce, red. T. Malecka, L. Polony, Kraków 1980, S. 23-24.

39 Tamże, s. 24.

40 Tamże.

41 B. Pociej, Bruckner - Mahler, [w:] Spotkania muzyczne w Baranowie 1977..., dz. cyt., s. 99.

42 R. Chłopicka, Tradycja gatunkowa w Pasji wg św. Łukasza Krzysztofa Pendereckiego, [w:] Spotkania muzyczne w Baranowie 1977..., dz. cyt., s. 193.

43 M. Tomaszewski, Muzyka Chopina na nowo odczytana. Studia i interpretacje, Kraków 1996, s. 117. 
Uszeregowanie, a więc szereg, czyli seria - kieruje nas to w stronę myślenia strukturalnego, właściwego dla muzyki dodekafonicznej i serialnej. Seria? Tak, jeśli układ ten zostanie użyty w technice seryjnej. Większość opracowań tematu B-A-C-H jest jednak tonalna i do tego - tematyczna ${ }^{44}$.

Wybór interwału znacząc e go w konstruowaniu serii jest typowy dla Schönbergowskiej dodekafonii. Jak zostało wykazane wcześniej, postać zasadnicza serii jest przeniknięta motywem B-A-C-H za sprawą odpowiedniego układu interwałowego. Motyw ten pojawia się zatem w dwojaki sposób: jako część składowa oryginalnego materiału dźwiękowego oraz jako cytat, w formie znanej i rozpoznawalnej. O ile obecność motywu jako „muzyki w muzyce” jest wyraźnie zaznaczona w introdukcji i w finale, o tyle w wariacjach jest on użyty jako element konstrukcyjny, a zatem ulegający przekształceniom (przykłady 5 i 6 ).

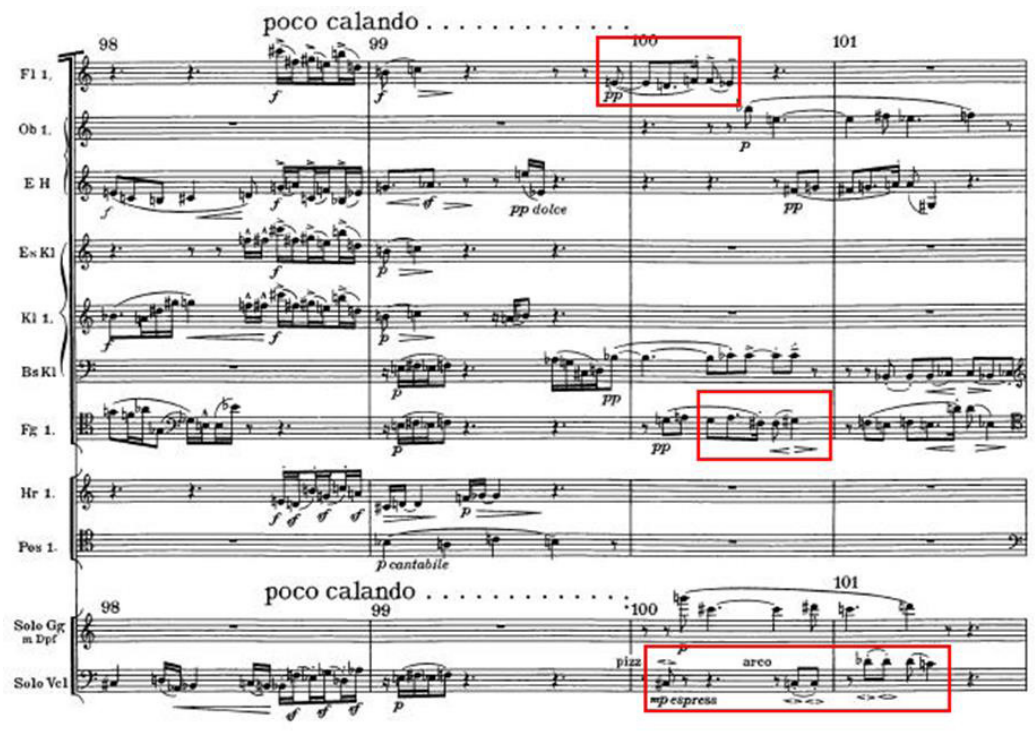

Przykład 5. A. Schönberg, Variationen für Orchester, t. 98-101. Permutacje motywu B-A-C-H (w partii pierwszego fletu i pierwszego fagotu) oraz interwał sekundy małej (reminiscencja introdukcji), przypominający cytat B-A-C-H (w partii wiolonczeli solo).

44 K. Szwajgier, dz. cyt., s. 745-746. 
Iwona Sowińska-Fruhtrunk, Różnica i powtórzenie jako aspekty reprezentacji...

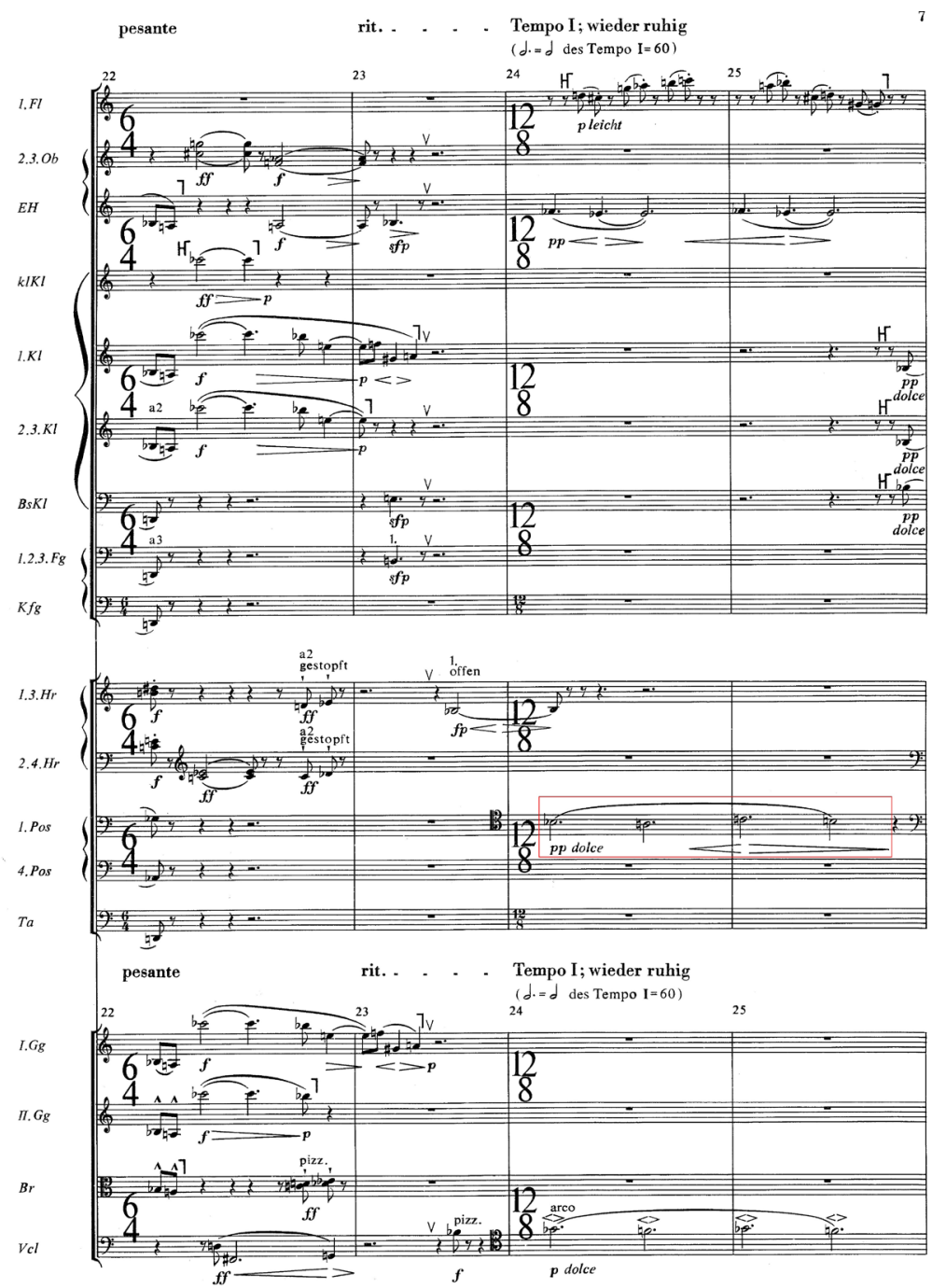

Przykład 6. A. Schönberg, Variationen für Orchester, t. 22-25. Pierwsze wystąpienie motywu B-A-C-H w introdukcji. 


\section{Różnica jako antyreprezentacja?}

Podstawę niniejszych rozważań o możliwości negacji reprezentacji za pomocą pojęcia różnicy stanowi myśl Gilles’a Deleuze’a: „Różnica może być wewnętrzna, a jednak nie pojęciowa" ${ }^{45}$. Filozof rozwija swoje spostrzeżenie: „Istnieją różnice wewnętrzne, które dramatyzują Ideę, zanim dokonają przedstawienia przedmiotu. Różnica jest tutaj wewnętrzna wobec Idei, chociaż jest zewnętrzna wobec pojęcia jako przedstawienia przedmiotu"46. Myśl ta nawiązuje do pojęcia Deleuzjańskiej wirtualności jako nieograniczonej potencjalności. Dopiero za sprawą jej aktualizacji zarówno idee, jak i wydarzenia mogą zaistnieć w konkretnej formie. Oznaczałoby to, że różnica pełni istotną funkcję już na poziomie wirtualnym i to właśnie dzięki niej idea nabiera ostatecznego kształtu, w przeciwieństwie do Heglowskiej wykładni idei, według której koncepcja i przedmiot stanowią jedność. Tak zdefiniowana różnica stanowi przyczynek do zastanowienia się nad relacją materii i formy w muzyce.

\section{1) Materia i forma}

Według Deleuze’a „forma różni się od materii [...], lecz nie na odwrót, ponieważ samo odróżnianie się jest formą" ${ }^{47}$. Różnica doskonała i jednocześnie największa to różnica ga tu nkowa (inaczej jest jedynie zwykłą odmiennością lub rozmaitością). Jako taka, jest ona zawsze pr zy c zy ną formalną ${ }^{48}$. Deleuze nie ma oczywiście na myśli gatunków muzycznych, jednak sam proces „odróżniania” jest podobny. W przypadku metody dodekafonicznej momentem czystej różnicy jest powstanie nowej, niepowtarzalnej serii (czym dodekafonia różni się od tonalności) z wirtualnej ${ }^{49}$ materii dźwiękowej. Następnie ulega ona dalszemu różnicowaniu za sprawą formy konkretnego utworu. Zatem zarówno forma, jak i konkretny, unikalny sposób organizacji materiału dźwiękowego przyczyniają się do podkreślenia różnicy. Jak

45 G. Deleuze, Różnica i powtórzenie, tłum. B. Banasiak, K. Matuszewski, Warszawa 1997, s. 6 o.

46 Tamże.

47 Tamże, s. 63.

48 Tamże, s. 67.

49 W znaczeniu Bergsonowskim i Deleuzjańskim. 
pisze Deleuze, różnica stawia opór, niczym wyjątek ${ }^{50}$, nie poddaje się syntezie, uogólnieniu. Filozof nawiązuje do odróżnienia władzy od mocy - tym, co daje moc, jest w muzyce ekspresja. Zbyt ogólne traktowanie pojęcia różnicy powoduje, że jest ono widziane zawsze przez pryzmat reprezentacji, podlega mediacji podobnie jak sam przedmiot przedstawienia. Tak rozumianym rodzajem reprezentacji jest już choćby sam sposób zastosowania serii w utworze, istotne jest zatem uchwycenie różnicy i jej potencjału już na poziomie materiału.

Różnica jest także tym, co powoduje, że przedmiot odcina się od swego podłoża. W Variationen za „podłoże" można uznać serię, można też za nie uznać temat, rozważając w jaki sposób „odcina” się on w wariacjach od „podłoża”, a następnie powraca do niego. Benič Zovko trafnie zauważa, że już sam temat jest wariacją serii ${ }^{51}$. Elementami kotwiczącymi są motyw B-A-C-H (w postaci oryginalnej) i kwinta czysta (aczkolwiek trudna w percepcji $w$ dalszym przebiegu utworu). Zróżnicowanie wynika zatem $z$ samej formy dzieła, jednak to odchodzenie od tematu jest podkreślone bardziej niż powracanie do niego, co ma związek z ulubioną techniką Schönberga - techniką „wariacji ewoluującej”"52.

2) Id ea „wariacji e wolu ującej” (entwickelnde Variation) jako przejaw „stawania się" (devenir)

Była już mowa o „muzyce w muzyce” w kontekście cytatu, natomiast sama forma wariacji bywa określana jako „muzyka o muzyce” ${ }^{53}$. W przypadku Schönbergowskich Variationen można mówić bardziej o „stawaniu się" niż cyrkularności (rozumianej jako powrót, apoteoza tematu na końcu utworu - tu apoteozie ulega raczej cytat). „Stawanie się” jest, według Deleuze’a i Guattariego, procesem ciągłym, dynamicznym, w którym wykształcona tożsamość jest chwilowa i prowadzi do kolejnego etapu. Tak rozumiane „stawanie się" odpowiada w pewien sposób technice „wariacji ewoluującej”, którą Carl Dahlhaus nazywa ideą „wariacji ewoluującej", a którą na potrzeby tej analizy autorka proponuje nazwać techniką „postępującego różnicowania”. Temat zostaje w kolejnych wariacjach tak oddalony od oryginału przez różnicowanie, że jego powrót jawi się jako

50 G. Deleuze, dz. cyt., s. 94.

51 M. Benič Zovko, dz. cyt., s. 50.

52 Tłumaczenie zaproponowane przez M. Trzęsioka, [w:] tegoż, Krzywe zwierciadło proroka. Rzecz o Księżycowym Pierrocie Arnolda Schönberga, Katowice 2002, s. 36.

53 Dyskusja końcowa, [w:] Spotkania muzyczne w Baranowie 1977..., dz. cyt., s. 292. 
reminiscencja, ślad, relikt, a nie element konstytutywny i napędowy struktury. Należy pamiętać, że temat to także seria, a ta powinna być obecna w całym materiale dźwiękowym. Kompozytor jednak zawiesza sformułowaną przez siebie zasadę (nie po raz ostatni), że żaden dźwięk serii nie powinien się powtórzyć przed jej całkowitym ukazaniem. Zatem seria w poszczególnych wariacjach także odcina się od swego wirtualnego „podłoża”, uprzywilejowuje różnicę. Jak pisze Benič Zovko, technika „wariacji ewoluującej” zapewnia jedność i koherencję szczególnie w tych wariacjach, w których temat został „wchłonięty" przez materiał dźwiękowy ${ }^{54}$, nie jest już rozpoznawalny słuchowo, a jedynie w zapisie nutowym. Koresponduje to $\mathrm{z}$ twierdzeniem Deleuzéa, że wieczny powrót jest bytem, ale wyłącznie bytem stawania się: „Powracanie jest [...] jedyną tożsamością, ale tożsamością jako mocą wtórną, tożsamością różnicy"55.

Wariacja I następuje attaca po temacie i brzmi quasi-konsonansowo za sprawą równoległych tercji i decym - techniki pochodzącej, według samego kompozytora, od podwójnego kontrapunktu decym i undecym, co pozwala na dodanie równoległych tercji do każdej partii ${ }^{56}$. Jest pod tym względem niejako rodzajem kontynuacji lirycznego charakteru tematu, który pojawia się tu jako cantus firmus (przykład 7).

Podstawową rolą kontrapunktu w utworze jest różnicowanie lirycznego tematu poprzez nadawanie mu zarówno energicznego, jak i statycznego charakteru. W wariacji IV temat zostaje "otoczony” czterogłosowym kontrapunktem, który paradoksalnie wysuwa się pod względem melodycznym i ekspresywnym na pierwszy plan i jest motorem całego przebiegu. Między głosami samego kontrapunktu nie ma jednak hierarchii. Z kolei wariacja VII (jedna z najbardziej rozbudowanych, utrzymana w metrum 4/4) jest rodzajem impresji dźwiękowej wynikającej z techniki kontrapunktycznej (utrzymana w tempie Langsam, w dynamice pp i ppp) i rozgrywa się w przeważającej mierze w wysokich rejestrach instrumentów. Na niedookreślony charakter brzmienia wpływa dodatkowo zróżnicowana artykulacja (przykład 8).

54 M. Benič Zovko, dz. cyt., s. 50.

55 G. Deleuze, dz. cyt., s. 8o.

56 A. Schoenberg, Style and Idea, dz. cyt., s. 237. 
Iwona Sowińska-Fruhtrunk, Różnica i powtórzenie jako aspekty reprezentacji...

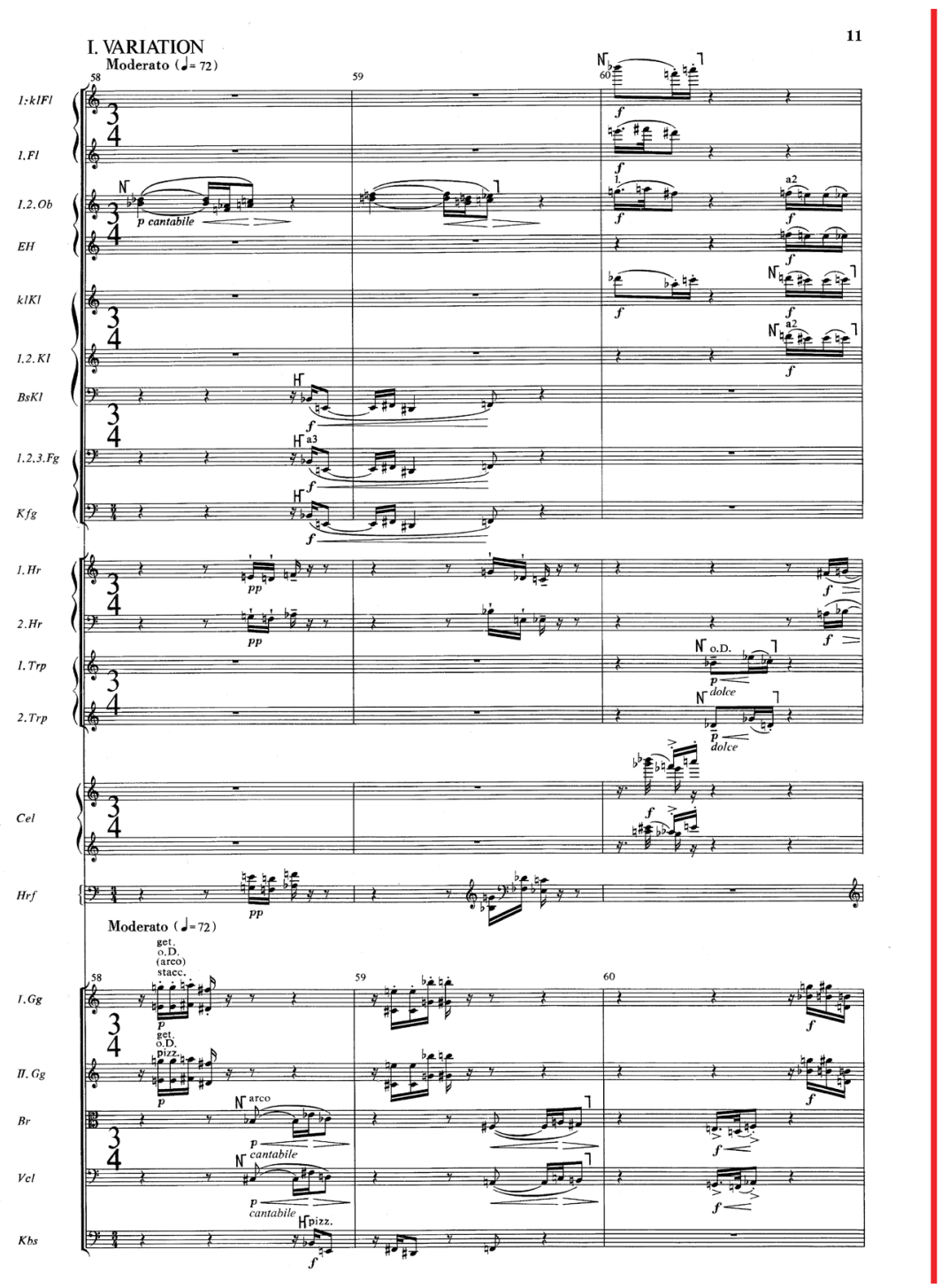

Przykład 7. A. Schönberg, Variationen für Orchester op. 31, wariacja I, t. 58-60. Cantus firmus i podwójny kontrapunkt. 


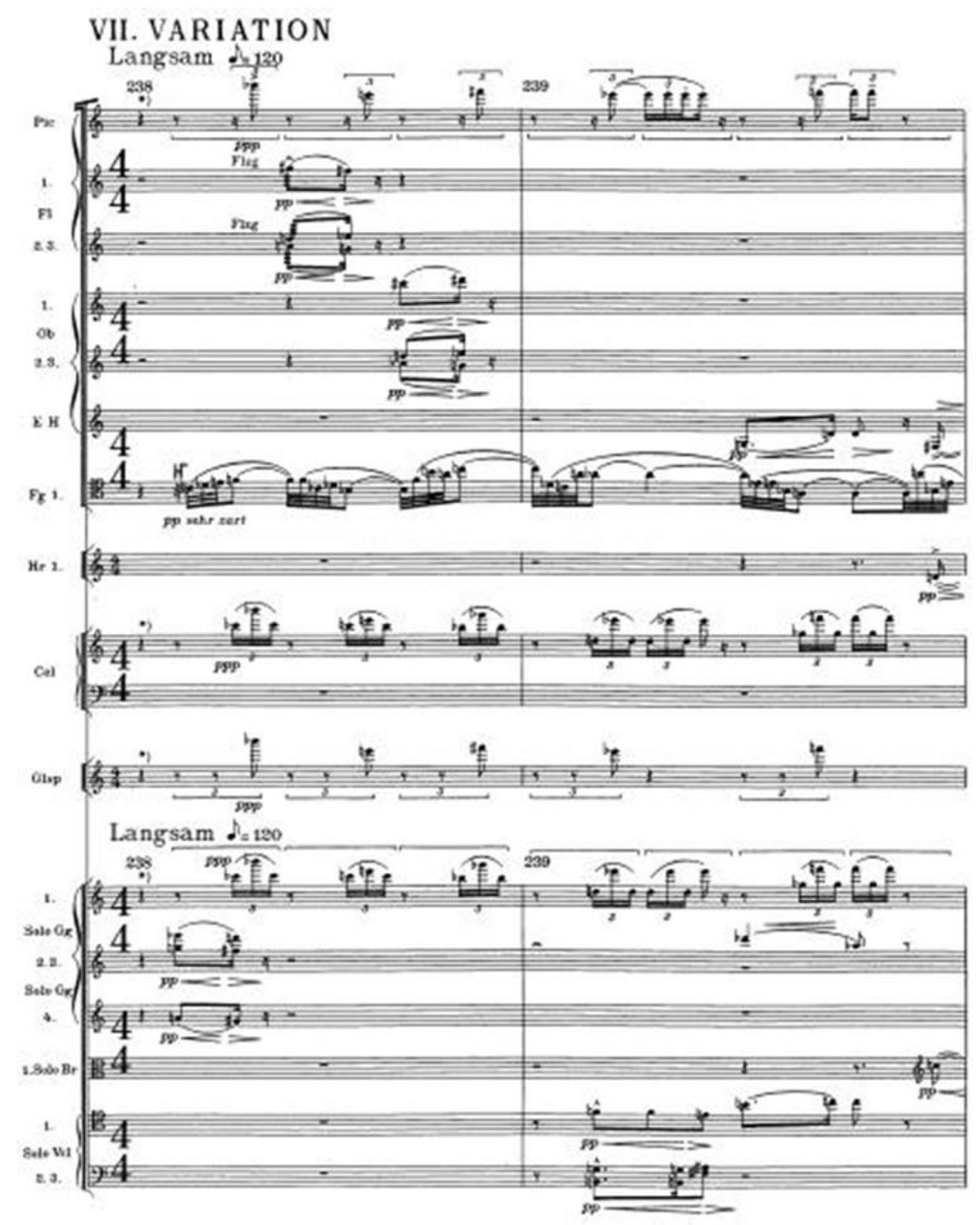

Przykład 8. A. Schönberg, Variationen für Orchester op. 31, wariacja VII, t. 238-239. Rodzaj impresji dźwiękowej.

Sposób, w jaki temat zostaje poddany „różnicowaniu” w kolejnych wariacjach, obejmuje nie tylko zmiany metrorytmiczne, agogiczne i dynamiczne, ale także nastrój wynikający z rodzaju ekspresji i „tonu”. 
3) Trzy płaszczyzny brzmieniowe

Trzy płaszczyzny brzmieniowe - tryton, kwinta czysta i antycypacja cytatu B-A-C-H - współistnieją w utworze niejako na zasadzie palimpsestu, w którym to, co dawniejsze, splata się z tym, co nowsze. Tryton mógłby być w takim ujęciu reprezentacją symbolu dysonansu, różnicy jako elementu „innego”, „obcego” w muzyce, także o złowrogim zabarwieniu (Fuxowski diabolus in musica). Kwinta czysta kojarzy się $\mathrm{z}$ reprezentacją natury - bywała często utożsamiana z muzycznym przedstawieniem pitagorejskiej harmonii, doskonałości i jednocześnie pierwotności wszechświata. Z kolei motyw B-A-C-H może być rozumiany (nie tylko w utworze Schönberga) jako reprezentacja sfery kultury, nie tylko poprzez oczywiste nawiązanie do postaci słynnego kompozytora, ale także za sprawą sposobu jej funkcjonowania w semiosferze. Obecność tych płaszczyzn jest dominująca zwłaszcza w introdukcji i w finale (czyli w ogniwach tworzących ramy całego cyklu), choć interwał kwinty czystej umyka percepcji słuchowej (przykład 9).

Płaszczyzny te dowodzą myślenia przestrzennego, ale także przywołują na myśl Deleuzjańską wersję przestrzeni rhizomatycznej. Zakłada ona swobodny ruch w każdym kierunku i brak opozycji przestrzennych, podobnie jak idealizowane przez Schönberga ujęcie przestrzeni Swedenborgowskiej. Odrzuca również obecność jakiegokolwiek centrum; jest pod tym względem niehierarchiczna i jednorodna, aczkolwiek zróżnicowana wewnętrznie. Kojarzy się bardziej z formą otwartą, jednak to nie stanowi jej najważniejszego aspektu. Seria dodekafoniczna poprzez eliminację powtórzeń zakłada równy status wszystkich dźwięków (co jednak w przypadku Schönberga często pozostaje jedynie teorią), zatem podobnie jak w koncepcji Deleuze'a nie dokonuje hierarchizacji. 


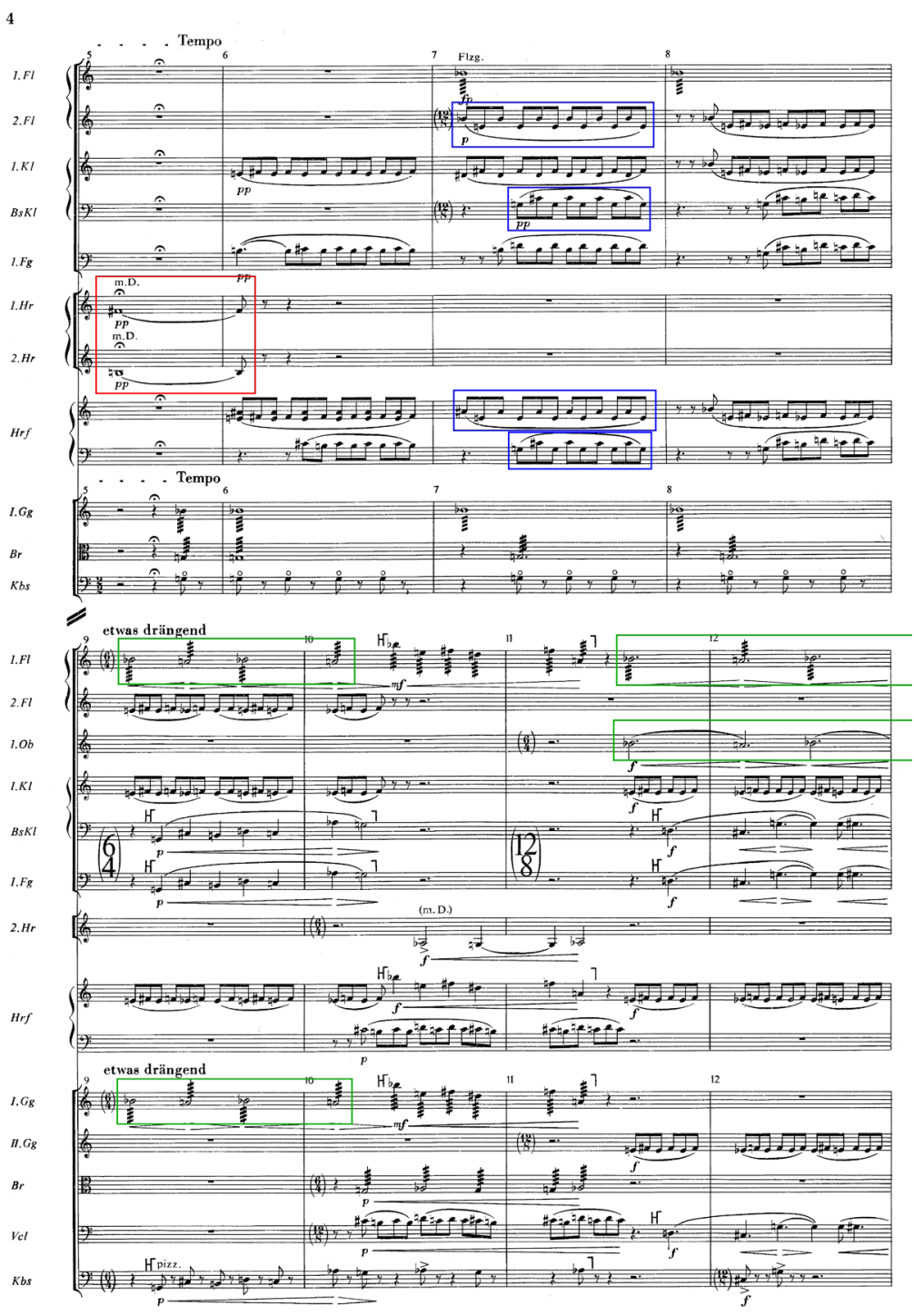

Przykład 9. A. Schönberg, Variationen für Orchester op. 31, introdukcja, t. 5-12. Trzy płaszczyzny w introdukcji: kwinta czysta (w partii waltorni, t. 5), tryton (flety, klarnet basowy i harfa, t. 7) i pierwsza część motywu B-A-C-H (pierwszy flet, pierwsze skrzypce, pierwszy obój, t. 9-12). 


\section{Interpretacja. Deleuzjańska koncepcja różnicy i powtórzenia}

Brian Hulse, podejmując zagadnienie „stosowalności” Deleuzjańskiej koncepcji różnicy w muzyce, zwraca szczególną uwagę na rolę kontrastu i opozycji1 ${ }^{57}$ - dwóch istotnych aspektów twórczości Schönberga w ogóle. Sam Deleuze uważał, że prawdziwa opozycja to nie maksimum różnicy, lecz minimum powtórzenia. Różnica występuje jako opozycja wobec siebie samej, nie zaś „zewnętrza” (nie tylko pozamuzycznego); pozostaje w ciągłym ruchu, jako proces „stawania się”. Ulegając jednak porównaniu (a występuje ono w każdym myśleniu opozycjami) ${ }^{58}$, traci część swojej niezależności. Dlatego tak istotne wydaje się przywołanie przez Schönberga Swedenborgowskiej przestrzeni w kontekście dodekafonii. Przykładowo, ponieważ nie istnieje w niej żadna hierarchia ani uprzywilejowanie kierunku, interwały nie powinny być porównywane ze sobą. Swobodny ruch we wszystkich kierunkach zakłada także pojęcie refrenu Deleuze’a i Guattariego. Taką rolę pełni w Variationen motyw B-A-C-H, stanowiący swego rodzaju kotwicę czy też wspomnianą przez Tomaszewskiego przystań, do której się ucieka lub z której się powraca ${ }^{59}$.

Dahlhaus zauważa, że „wariacja ewoluująca” różni się od pracy motywiczno-tematycznej przede wszystkim wyższym stopniem abstrakcji, na który pozwala i którego wręcz wymaga ${ }^{60}$. Rdzeń Schönbergowskiej idei muzycznej zawiera się, zdaniem badacza, w interwale, natomiast inne elementy (harmonia, rytm) służą jedynie prezentacji tej idei - co nie oznacza, że są ignorowane ${ }^{61}$. Dahlhaus uważa, że z tego właśnie powodu prawdziwą substancję muzyki Schönberga, zwłaszcza twórczości dodekafonicznej, stanowi diastematyczność. W pojęciu „wariacji ewoluującej” pierwszy człon oznacza namacalny aspekt techniki kompozytorskiej, natomiast ewolucja (rozwój) stanowi formę interpretacji estetycznej6 ${ }^{62}$. Kiedy drugi motyw powstaje z pierwszego,

57 B. Hulse, Thinking Musical Difference: Music Theory As Minor Science, [w:] Sounding the Virtual: Gilles Deleuze and the Theory and Philosophy of Music, red. B. Hulse, N. Nesbitt, Burlington 2010, s. 25.

58 Jak pisał Deleuze, u Arystotelesa „największą różnicą jest zawsze przeciwieństwo”. Zob. G. Deleuze, dz. cyt., s. 66.

59 M. Tomaszewski, Na otwarcie..., dz. cyt., s. 25.

60 C. Dahlhaus, Schoenberg and the New Music, Cambridge 1990, s. 130.

61 Tamże, s. 131.

62 Tamże, s. 132. 
a trzeci z drugiego, nie oznacza to, że trzeci i pierwszy motyw posiadają wciąż jakąś cechę wspólną. Na tym właśnie polega różnica pojmowana w opozycji do organicznej koncepcji formy muzycznej, zakładającej rozwój z jednego ziarna, który jest możliwy do prześledzenia wstecz w każdym momencie. Warto podkreślić, że technika „wariacji ewoluującej" była jedną z nielicznych, którym kompozytor pozostał wierny do końca życia ${ }^{63}$.

\section{Powtórzenie i różnica}

Zdaniem Eugene’a W. Hollanda dwoma głównymi problemami powtórzenia filozoficznego są trwanie i mimesis (jako imitacja) ${ }^{64}$. Cykliczna reprezentacja czasu była typowa dla prymitywnych i wczesnoreligijnych społeczeństw, a także dla sfery mitu ${ }^{65}$. W filozofii aż do Kierkegaarda, Nietzschego, Derridy i Deleuzéa powtórzenie nigdy nie oznaczało czegoś nowego, lecz raczej coś statycznego. Dopiero wymienieni myśliciele uznali powtórzenie za „siłę, która symultanicznie o d t wa r z a jedną rzecz i two r zy inną rzecz na no w o"66. Zarówno dla Derridy, jak i dla Deleuze’a powrót identycznego jest teoretycznie niemożliwy, gdyż sam fakt powrotu "tego Samego" już sprawia, że jest ono inne ${ }^{67}$. Co więcej, Holland uważa, że koncepcja „oryginału” jest możliwa tylko ze względu na potencjalne powtórzenie, które „waha się pomiędzy «re-prezentacją» (tzw. modelem platońskim) i pre-prezentacją [...], podaje w wątpliwość «absolutne» $\mathrm{i}$ «podstawowe» pojęcia «oryginału» $\mathrm{i}$ «źródła»"68.

Zrozumienie wagi powtórzenia jest kluczowe dla interpretacji twórczości Schönberga. Dla kompozytora „powtórzenie jest zasadą strukturalną koherencji" ${ }^{\circ}$, co oznacza przede wszystkim ustalenie reguł powtarzania motywu muzycznego ${ }^{70}$. Jedynym sposobem rozpoznania

63 Tamże, s. 88.

64 E.W. Holland, Deleuze and Guattari's A Thousand Plateaus, London-New York 2014, s. 3-30.

65 Tamże, s. 3.

66 Tamże, s. 6.

67 Tamże, s. 19.

68 Tamże.

69 A. Schoenberg, Coherence, Counterpoint, Instrumentation, Instruction in Form, Lincoln 1994, s. 37.

70 Tamże, s. 36. 
kombinacji wariantów jest podążanie za zasadami logiki i rozumienie formy muzycznej ${ }^{71}$. Warunkiem podstawowym zrozumienia jest pamięć, natomiast warunkiem wstępnym pamięci - rozpoznanie. Pamięć jest blisko powiązana ze wspomnieniem, jednakże wspomnienie czyni moment przeszły statycznym, podczas gdy pamięć działa w sposób synchroniczny.

Dla Schönberga „powtórzenie jest pierwszym etapem muzycznej techniki formalnej, natomiast wariacja i przetworzenie - stadiami wyższymi"72. Kompozytor podaje jako przykład formę ronda, w której myśl muzyczna, czyli główny temat ronda

jest powtarzana, jednak z innego powodu niż refren: powtórzenie jest tutaj jedynym sposobem na rozwijanie tematu, podczas gdy np. w poemacie literackim sama idea jest rozwijana w niepowtarzających się strofach - to one potwierdzają trafność refrenu i nadają wyraz sednu jego znaczenia: faktowi, że różne rzeczy mogą być równe, podobne lub powiązane 73 .

Powtórzenie w muzyce - zwłaszcza w wariacjach - pokazuje, że róż n e rzeczy mogą powstać z je dn e j, poprzez rozwój i przetwarzanie, poprzez generowanie nowych figur ${ }^{74}$. „Definiuję wariację jako zmianę pewnej liczby cech fragmentu, z jednoczesnym zachowaniem innych w niezmiennym kształcie"75, pisał Schönberg. Taka wariacja jest formą powtórzenia i służy osiągnięciu koherencji. To, co kompozytor nazywa wariantami i „wariacją ewoluującą", jest w istocie rezultatem myślenia Deleuzjańską czystą różnicą. Schönberg miał poczucie, że pojęcie powtórzenia rozumiane w sposób ogólny nie przystaje do jego dzieł, gdyż odnosi się do pewnej cechy o charakterze statycznym.

Deleuze uważa, że „powtórzenie nie jest ogólnością"76, gdyż ogólność ma dwa porządki: jakościowy porządek podobieństw i ilościowy

71 A. Schoenberg, Style and Idea, dz. cyt., s. 102-103.

72 Tamże, s. 265.

73 Tamże, s. 266. Warto w tym miejscu zwrócić uwagę na fakt, że Schönberg odróżnia powtarzalność tematu ronda (zwanego w potocznej terminologii muzycznej refrenem) od refrenu $\mathrm{w}$ formie literackiej. Podkreśla przy tym pozytywny charakter różnicy („równe, podobne lub powiązane”), sugerowany w interpretacji Deleuzjańskiej.

74 Tamże.

75 Tamże, s. 287.

76 G. Deleuze, dz. cyt., s. 27. 
porządek ekwiwalentów. Przez ogólność filozof rozumie „punkt widzenia, zgodnie z którym jeden termin można wymienić na inny lub innym zastąpić" 77 . Natomiast powtórzenie, jak pisze Deleuze, „jest konieczne i usprawiedliwione tylko w relacji do tego, co nie może zostać zastąpione"78. Skoro nie można znaleźć ekwiwalentu, substytutu, można tylko dokonać powtórzenia (jak w przypadku motywu B-A-C-H w Variationen). Stąd tak silny związek powtórzenia z pojęciem oryginalności, a $\mathrm{w}$ dalszej kolejności z reprezentacją (zwłaszcza rozumianą jako refleks czy echo). Tak jak nie sposób dokonać substytucji duszy ${ }^{79}$, tak nie sposób zastąpić istoty dzieła (reprezentowanego). Deleuze zwraca uwagę na fakt, że powtórzenie i podobieństwo pochodzą $\mathrm{z}$ różnego porządku: powtórzenie może być „reprezentowane” przez podobieństwo, ale wciąż będzie zawierać różnicę ${ }^{80}$. Filozof krytykuje w gruncie rzeczy zasadę tożsamości: wszelkie koncepcje mogą podlegać czystej różnicy lub złożonemu powtórzeniu. Rozumiane $\mathrm{w}$ ten sposób powtórzenie jest „nieświadomością reprezentacji”"81.

Bogdan Banasiak pisze: „Myślenie jest [...] grą różnicy i powtórzenia. $Z$ tego też względu tradycyjne rozumienie podmiotu jako identycznego z cogito również musi ulec przekształceniu, podmiot konstytuowany jest bowiem nie tyle przez poznanie, ile przez pożądanie lub przepływ intensywnych wielości" 82 . Różnica sama w sobie posiada niejasny i zmienny status ontologiczny, gdyż pozostaje w ciągłym ruchu i ulega przekształceniom. Gdy tylko osiągnie cel, przestaje być różnicą. Deleuze uważał, że Arystotelesowska niemożność pojmowania różnicy bez odniesienia do tożsamości zaciążyła na całej zachodniej tradycji myślenia racjonalnego ${ }^{83}$. Fakt ten zaważył także $\mathrm{w}$ istotny sposób na postrzeganiu reprezentacji. To właśnie reprezentacja pozwalała na obecność podobieństwa, tożsamości, powtórzenia. Dlatego czasami nazywa się refleksję Deleuze’a "ruiną reprezentacji" ${ }^{4}$. Jednak, jak

77 Tamże.

78 Tamże.

79 Tamże.

80 Tamże.

81 Tamże, s. 17.

82 B. Banasiak, Bez różnicy, http://bb.ph-f.org/teksty/bb_bez_roznicy.pdf [dostęp: 03.04.2017], s. 15.

83 E. Prieto, Deleuze, Music..., dz. cyt., s. 7-8.

84 Por. tytuł pracy: D. Olkowski, Gilles Deleuze and the Ruin of Representation, Berkeley 1999. 
zauważa Eric Prieto, kwestionowanie reprezentacji prowadzi filozofa (wspólnie z Félixem Guattarim) z powrotem ku niej za pośrednictwem pojęcia refrenu ${ }^{85}$.

\section{Refren}

Wydawałoby się, że $\mathrm{w}$ formie wariacji temat może występować $\mathrm{w}$ roli refrenu (w rozumieniu filozoficznym, nie muzycznym). Tak też bywa $\mathrm{w}$ wariacjach klasycznych. Jednak u Schönberga następuje zderzenie dwóch przeciwstawnych sił: tematu poddanego „stawaniu się" oraz cytatu-tematu jako rodzaju zakotwiczenia, niepozwalającego wyzwolić się „prawdziwemu” tematowi wariacji. Co ciekawe, motyw B-A-C-H pojawia się w długich wartościach, na wzór cantus firmus, natomiast $\mathrm{w}$ wariacjach to temat właściwy jest prezentowany w ten sposób. Odsłania się tu zatem pewna zasada konstrukcyjna. Bogumiła Mika zalicza motyw B-A-C-H do cytatów-sygnatur w funkcji indeksykalnej ${ }^{86}$, czyli pojawiających się na zasadzie intencjonalnego wskazania na danego twórcę. Mika jednak niefortunnie interpretuje ten motyw w Variationen Schönberga jako temat przypadkowy, incydentalny ${ }^{87}$, czemu zaprzecza przeprowadzona tutaj analiza. Z kolei Krzysztof Szwajgier tak definiuje symbolikę motywu B-A-C-H (w odniesieniu do Kwartetu smyczkowego op. 28 Antona Weberna):

Dośrodkowy układ tercji małej, otoczonej dwiema małymi sekundami, jest silnie nasycony ekspresywną symboliką. Kondensacja tego ukształtowania porównywalna jest - wśród czterodźwiękowych tematów - jedynie z „motywem losu" Beethovena. Tutaj smutek, melancholia, wyraz żalu, błaganie, łkanie, przygnębienie - to kategorie, [które] należałoby przywołać przede wszystkim, czy to wychodząc od reguł alegorii muzycznych, czy też od powszechnego doświadczenia. Całość w sposób naturalny dzieli się na dwie części, przez co otrzymujemy motyw zapytania i odpowiedzi, która jest tym samym (zapytaniem). To nie dialog, lecz rozmyślanie człowieka samotnego ${ }^{88}$.

85 E. Prieto, dz. cyt., s. 9.

86 B. Mika, Cytaty w muzyce polskiej XX wieku. Konteksty, fakty, interpretacje, Katowice-Kraków 2008, s. 252.

87 Tamże, s. 253.

88 K. Szwajgier, dz. cyt., s. 745. 
Interesujące, że w utworze Schönberga motyw ten zostaje niemal zupełnie pozbawiony wyrazu smutku i żalu. Rodzi się pytanie, czy te aspekty są zatem immanentne dla motywu B-A-C-H, czy też pojawiają się tylko w odpowiednim kontekście? Pewną wskazówką może być fakt, że Schönberg (w przeciwieństwie do Weberna, według Szwajgiera) podejmuje dialog z przeszłością, czego najdobitniejszym przykładem jest finał wariacji. Charakter tego dialogu odpowiada wyróżnionym przez Mieczysława Tomaszewskiego trzem sposobom funkcjonowania cytatu w muzyce, spośród których Variationen obejmuje po pierwsze sytuację cytatu jako punktu odniesienia dla muzyki nowej, po drugie - sytuację wzbogacenia muzyki nowej poprzez cytat (jako muzyka inkluzywna) ${ }^{89}$.

Taki sposób funkcjonowania cytatu odpowiada pojęciu refrenu w interpretacji Deleuze’a i Guattariego. Jak pisze Eric Prieto:

\section{Deleuze i Guattari nie uznają muzyki za sztukę abstrakcyjną, beztreściową czy też niereprezentującą. Wręcz przeciwnie, podkreślają fakt, że każda muzyka posiada zawartość tematyczną nierozerwalną z jej formą i nieróż- niącą się w żaden istotny sposób od rodzajów treści obecnych w literaturze. Utożsamiają oni tę zawartość z muzyką z refrenem ${ }^{90}$.}

To właśnie pojęcie refrenu czyni reprezentację możliwą. Deleuze i Guattari nazywają go wręcz wiecznym powrotem - rozumianym jako cykl lub cyrkulacja, wreszcie jako moment największej stabilności w pieśni. Muzyka jednak czyni wszystko, aby refren zdestabilizować, „zdeterytorializować”, gdyż ogranicza on ze swej natury procesy muzycznego przetwarzania.

\section{Variationen für Orchester op. 31 - podsumowanie}

Schönberg używa cytatu B-A-C-H jako motywu powtarzającego się w czasie, lecz o statycznej naturze (w introdukcji), która zapewnia mu rozpoznawalność nawet w skomplikowanej fakturze. Motyw ten jawi się jako relikt świata zewnętrznego w dziele, używając sformułowania

89 M. Tomaszewski, Utwór muzyczny w perspektywie intertekstualnej, [w:] tenże, Muzyka polska w perspektywie intertekstualnej. Studia i szkice, Kraków 2005, s. 32. 90 E. Prieto, dz. cyt., s. 13. 
Mieczysława Tomaszewskiego ${ }^{91}$. Z kolei w finale wariacji motyw ten pełni funkcję strukturalną, a nie tylko skojarzeniową. Według Deleuze’a powtarzać oznacza nie znajdować ekwiwalentu, stąd jeśli coś jest niezastępowalne, może być tylko powtórzone. Louis Marin pisze: „[...] cytat, poprzez wydobycie pewnego tekstu i umieszczenie go poza jego systemem i przemieszczenie do innego tekstu należącego do innego systemu, stanowił ostateczne spełnienie się procesu mimetycznego czy przedstawieniowego"92.

Wskazując na formę wariacji, Schönberg wyraził swoje zdanie na temat ambiwalencji czysto muzycznej różnicy i powtórzenia:

\footnotetext{
„Cokolwiek wydarza się w utworze muzycznym, nie jest niczym innym niż niekończącym się kształtowaniem na nowo podstawowego kształtu". Lub, innymi słowy, nie ma w muzyce nic innego niż to, co pochodzi z tematu, wyrasta z niego i może być z powrotem do niego sprowadzone; formułując to jeszcze dobitniej, nic poza samym tematem. Wszelkie kształty pojawiające się w utworze są pr zewidzian e w „temacie"93.
}

Temat służy zatem jako punkt wyjścia i zawiera potencjalne (wirtualne, jak by powiedział Deleuze) możliwości „przyszłego wykorzystania podstawowego materiału"94. Schönberg wykorzystuje w introdukcji trzy różne elementy, tworzące płaszczyzny w wielowymiarowej przestrzeni: kwintę czystą (jako reprezentację „natury”), motyw B-A-C-H (jako reprezentacje „kultury”) i interwał trytonu (jako reprezentację „symbolu”). Materiał utworu jest dodekafoniczny i to seria jest elementem, który przynosi różnicę. W introdukcji słyszymy powtarzającą się antycypację materiału tematycznego. Motyw B-A-C-H i temat wariacji sugerują doświadczenie „podwójnego czasu” - zakotwiczenie i ruch jednocześnie, różne tempo przebiegu, ale w zunifikowanym przepływie. O antycypacji dowiadujemy się, spoglądając wstecz, co pozostaje w ścisłej relacji z Schönbergowską przestrzenią jako jednością i z Deleuzjańskim pojęciem refrenu - ruch w każdą stronę jest możliwy.

91 M. Tomaszewski, Utwór muzyczny jako refleks, odblask, relikt i echo rzeczywistości poza-dziełowej. Rekonesans, „Teoria Muzyki. Studia, interpretacje, dokumentacje” 5 (2016), nr 8/9, s. 492.

92 L. Marin, Mimesis i opis albo ciekawość metody [w:] tegoż, O przedstawieniu, tłum.

P. Pieniążek, Gdańsk 2011, s. 96-97.

93 A. Schoenberg, Style and Idea, dz. cyt., s. 290.

94 Tamże. 
Seria ukazuje się zatem zarówno wertykalnie, jak i horyzontalnie bez uprzywilejowania żadnego wymiaru.

Można analizować cechy szczególne Variationen für Orchester w ramach prostych opozycji: statyczny / dynamiczny, symetryczny / asymetryczny, cytat / seria, powtórzenie / „wariacja ewoluująca”, czyli korzystając z ogólnego wzoru negatywne / pozytywne. Oznaczałoby to jednak minimalizację różnicy. Jak pisze Christopher Hasty, coś, co jest statyczne, nie może reprezentować prawdziwego doświadczenia ${ }^{95}$. Deleuze nazywa taki stan „obrazem myśli” lub, innymi słowy, rozpoznaniem. Myśl i obraz są niczym „to samo” i „podobne” w reprezentacji. Jak pisze Hasty, „,rozpoznanie [...] dociera do rzeczy wstecz, poruszając się w nieprawidłowym kierunku - wywodząc transcendentalne z empirycznego" 96 . To może być powód niemożności pełnego zwerbalizowania przez Schönberga koncepcji idei muzycznej. Nowe, aktualne doświadczenie (gdy przemija) zmienia wirtualność, potencjalność dla kolejnych doświadczeń ${ }^{97}$.

\section{Bibliografia}

Banasiak B., Bez różnicy, [online] http://bb.ph-f.org/teksty/bb_bez_roznicy.pdf [dostęp: 03.04.2017].

Benič Zovko M., Twelve-Tone Technique and Its Forms: Variation Techniques of Arnold Schoenberg's "Variations for Orchestra" Op. 31, "International Review of the Aesthetics and Sociology of Music" 38 (2007), nr 1.

Berger K., Diegesis and Mimesis: The Poetic Modes and the Matter of Artistic Presentation, „The Journal of Musicology” 12 (1994), nr 4.

Cherlin M., Dialectical Opposition in Schoenberg's Music and Thought, "Music Theory Spectrum” 22 (2000), nr 2.

Chłopicka R., Tradycja gatunkowa w „Pasji wg św. Łukasza” Krzysztofa Pendereckiego, [w:] Spotkania muzyczne w Baranowie 1977. Muzyka w muzyce, red. T. Malecka, L. Polony, Kraków 1980.

Dahlhaus C., Arnold Schönberg, Variationen für Orchester, München 1968.

95 C. Hasty, The Image of Thought and Ideas of Music, [w:] Sounding the Virtual..., dz. cyt., s. 4.

96 Tamże, s. 7.

97 Tamże, s. 8. 
Dahlhaus C., Schoenberg and the New Music, Cambridge 1990.

Deleuze G., Różnica i powtórzenie, tłum. B. Banasiak, K. Matuszewski, Warszawa 1997.

Deleuze G., F. Guattari, Tysiąc plateau, tłum. M. Herer, Warszawa 2015.

Grosz E., Chaos, Territory, Art: Deleuze and the Framing of the Earth, New York 2008.

Haimo E., Variationen für Orchester, op. 31, [w:] Schönberg, Interpretationen seiner Werke, red. G. Gruber, Wien 2002.

Hasty C., The Image of Thought and Ideas of Music, [w:] Sounding the Virtual: Gilles Deleuze and the Theory and Philosophy of Music, red. B. Hulse, N. Nesbitt, Burlington 2010.

Holland E.W., Deleuze and Guattari's A Thousand Plateaus, LondonNew York 2014.

Hulse B., Thinking Musical Difference: Music Theory As Minor Science, [w:] Sounding the Virtual: Gilles Deleuze and the Theory and Philosophy of Music, red. B. Hulse, N. Nesbitt, Burlington 2010.

Johnson J., Webern and the Transformation of Nature, Cambridge 1999.

Krones H., Arnold Schönberg, Wien 2005.

Marin L., Mimesis i opis albo ciekawość metody, [w:] tenże, O przedstawieniu, tłum. P. Pieniążek, Gdańsk 2011.

Mika B., Cytaty w muzyce polskiej XX wieku. Konteksty, fakty, interpretacje, Katowice-Kraków 2008.

Muxeneder T., Variationen für Orchester [Variations for Orchestra] Op. 31 (1926-28), [online] http://www.schoenberg.at/index.php/ en/joomla-license-sp-1943310036/variationen-fuer-orchesterop-31-1926-1928 [dostęp: 02.08.2017].

Olkowski D., Gilles Deleuze and the Ruin of Representation, Berkeley 1999.

Pociej B., Bruckner - Mahler, [w:] Spotkania muzyczne w Baranowie 1977. Muzyka w muzyce, red. T. Malecka, L. Polony, Kraków 1980.

Prieto E., Deleuze, Music, and Modernist Mimesis, [online] https://www. academia.edu/580419/Deleuze_Music_and_Modernist_Mimesis [dostęp: 12.03.2017].

Prieto E., Listening In: Music, Mind, and Modernist Narrative, London 2002.

Rognoni L., Wiedeńska szkoła muzyczna. Ekspresjonizm i dodekafonia, tłum. H. Krzeczkowski, Kraków 1978.

Schoenberg A., Style and Idea, Berkeley 2010. 
Schoenberg A., Coherence, Counterpoint, Instrumentation, Instruction in Form, Lincoln 1994.

Schoenberg A., Theory of Harmony, tłum. R.E. Carter, Berkeley-Los Angeles 1983.

Szwajgier K., Webern, B-A-C-H, C-A-G-E i Czwórca, [w:] Muzyka w kontekście kultury, red. M. Janicka-Słysz, T. Malecka, K. Szwajgier, Kraków 2001.

Tomaszewski M., Muzyka Chopina na nowo odczytana. Studia i interpretacje, Kraków 1996.

Tomaszewski M., Na otwarcie: dlaczego muzyka w muzyce, [w:] Spotkania muzyczne w Baranowie 1977. Muzyka w muzyce, red. T. Malecka, L. Polony, Kraków 1980.

Tomaszewski M., Utwór muzyczny jako refleks, odblask, relikt i echo rzeczywistości poza-dziełowej. Rekonesans, „Teoria Muzyki. Studia, interpretacje, dokumentacje" 5 (2016), nr 8/9.

Tomaszewski M., Utwór muzyczny w perspektywie intertekstualnej, [w:] tenże, Muzyka polska w perspektywie intertekstualnej. Studia i szkice, Kraków 2005.

Trzęsiok M., Krzywe zwierciadło proroka. Rzecz o „Księżycowym Pierrocie" Arnolda Schönberga, Katowice 2002.

Trzęsiok M., Narodziny dodekafonii $z$ ducha teozofii? Schönberg, Swedenborg i metempsychoza, [w:] Kompozytor $i$ jego świat. Bronisław Kazimierz Przybylski in memoriam, red. E. KowalskaZając, M. Szoka, Łódź 2012. 